\title{
Analgesic Effects of Erythrina variegata L. Leaves and Soft Stems in Mice
}

\author{
Mostafi Jumrut Mahal, Zubaida Khatun, Tozammal Hossain, Abdullah Al Mamun, \\ Mohammad Shahadat Hossain, Asish Kumar Das, \\ Mst. Afsana Khatun*, Mohammed Rahmatullah** \\ Department of Biotechnology and Genetic Engineering, \\ University of Development Alternative, Dhaka-1205, Bangladesh \\ *Present address: Dept. of Pharmacy, Lincoln College, Mayang Plaza, Block A, No 1, Jalan SS 26/2, \\ Taman Mayang Jaya, 47301, Petaling Jaya, Selangor Darul Ehsan, Kuala Lumpur, Malaysia
}

\begin{abstract}
Methanolic extract of leaves and soft stems of Erythrina variegata (EVLSS) was investigated for analgesic activity at the doses of 50,100, 200 and $400 \mathrm{mg} / \mathrm{kg}$ body weight orally. All the doses of EVLSS significantly attenuated the writhing responses induced by intraperitoneal injection of acetic acid in mice.
\end{abstract}

Keywords: Erythrina variegata, acetic acid, analgesic activity, gastric writhing.

\begin{abstract}
Introduction
Erythrina variegata L. (Fabaceae), commonly known as Mandar, Tiger's Claw, Indian Coral Tree and Sunshine Tree grows commonly in different parts of Bangladesh ${ }^{[1]}$. The tree is well adapted to the humid tropics and subtropics and even can tolerate a wide variety of climates within this zone ${ }^{[2]}$. This plant is well known in folklore medicine of Bangladesh, where both leaves and stems are used in combination. Its leaves are believed to have analgesic, anthelmintic, laxative and diuretic properties; its barks are used in treating leprosy and fever and also used as febrifuge, and astringent ${ }^{[3]}$. Local folk medicinal practitioners often use paste of soft stem and leaves for the treatment of joint pain. A scientific evaluation of the analgesic activity of only leaf extract of this plant has been carried out ${ }^{[4]}$. The present study was therefore designed to evaluate the analgesic activity of methanolic extract of both leaf and soft stems of E. variegata and compare with the analgesic effect showed by leaf only as reported by Haque et al. ${ }^{[4]}$.
\end{abstract}

\section{Materials and Methods}

\section{Collection of plant material}

The leaves and soft stems of E. variegata were collected during June 2009 from Savar, Dhaka, Bangladesh. The leaves and stems were identified at the Bangladesh National Herbarium where a sample specimen was also deposited.

\section{Preparation of the test samples}

The dried leaves and soft stems (sun-dried for 5 days) of E. variegata were pulverized into a fine powder and were mixed with methanol at a ratio of 1:5 (100g leaves and stems in $500 \mathrm{ml}$ methanol). After 24 hours, the mixtures were filtered; filtrate was collected and the residue was again mixed with methanol at a ratio of 1:3 (100g leaves and stems in $300 \mathrm{ml}$ methanol) for 24 hours. After filtration, filtrates were combined and evaporated to dryness using a rotary evaporator.

\footnotetext{
** Corresponding Author: Email: rahamatm@hotmail.com
} 


\section{Animals}

Swiss albino mice (20 - $25 \mathrm{~g})$ of either sex were obtained from the animal house of International Center for Diarrhoeal Disease and Research, Bangladesh (ICDDR, B). The animals were given standard feed developed by ICDDR, B and water ad libitum and kept in the laboratory environment (relative humidity $55-65 \%$, room temperature $25.0 \pm 2^{\circ} \mathrm{C}$, and 12 hours light/dark cycle) for seven days for acclimatization. Animals were kept under fasting for overnight and weighed before the experiment. The study was approved by the Institutional Animal Ethical Committee of University of Development Alternative, Dhaka, Bangladesh.

\section{Studied activity}

Analgesic activity of EVLSS was tested using the acetic acid-induced writhing method as described by Mani et al. with minor modifications ${ }^{[7]}$. In brief, albino mice were divided into six groups having six animals in each group. The animals were pre-treated with the extract $(50,100,200$ and 400 $\mathrm{mg} / \mathrm{kg}$, p.o.) or aspirin ( $200 \mathrm{mg} / \mathrm{kg}$, p.o) used as standard drug, 1 hour prior to intraperitoneal injection of $1 \%(\mathrm{v} / \mathrm{v})$ acetic acid $(0.1 \mathrm{ml} / 10 \mathrm{~g})$. Five minutes after the intraperitoneal injection of acetic acid, the number of writhing during the following 10 minutes was counted. Control mice were administered vehicle $(0.5 \%$ carboxymethylcellulose sodium; $10 \mathrm{ml} / \mathrm{kg})$.

\section{Statistical Analysis}

The results are expressed as mean \pm S.E.M. Statistical difference was tested by using Student's $t$-test. $P<0.05$ was considered as statistically significant.

\section{Result}

The oral treatment of mice with EVLSS $\quad(50,100,200$ and $400 \mathrm{mg} / \mathrm{kg})$ produced a significant $(P<$ $0.01)$ and dose dependent inhibition in abdominal writhing produced by acetic acid. The inhibition by EVLSS ( $200 \mathrm{mg} / \mathrm{kg}$, p.o.) was nearly similar to that produced by aspirin $(200 \mathrm{mg} / \mathrm{kg}$, p.o.). EVLSS at 400/kg dose showed $60.01 \%$ inhibition, which was higher than that obtained with the standard drug, aspirin (55.96\%, Table 1). Any toxic effects were not noticed in mice up to extract dose of $400 \mathrm{mg} / \mathrm{kg}$ body weight.

Table 1: Analgesic activity of EVLSS in acetic acid-induced writhing test

\begin{tabular}{llll}
\hline Groups & $\begin{array}{l}\text { Dose } \\
(\mathrm{mg} / \mathrm{kg})\end{array}$ & $\begin{array}{l}\text { Number of writhing } \\
(\text { mean } \pm \text { SEM })\end{array}$ & $\begin{array}{l}\text { Inhibition } \\
(\%)\end{array}$ \\
\hline Control & 0.5 & $33.33 \pm 3.95$ & $55.96^{*}$ \\
Aspirin & 200 & $14.67 \pm 3.41$ & $48.01^{*}$ \\
Extract of E. variegata & 50 & $17.33 \pm 4.19$ & $54.01^{*}$ \\
Extract of E. variegata & 100 & $15.33 \pm 1.23$ & $57.01^{*}$ \\
Extract of E. variegata & 200 & $14.33 \pm 3.32$ & $60.01^{*}$ \\
Extract of E. variegata & 400 & $13.33 \pm 2.23$ & \\
\hline
\end{tabular}

The writhing in control was considered as $100 \%$. Data presented here as Mean \pm S.E.M $(\mathrm{n}=6) .{ }^{*} P<0.01$ as compared to control group. 


\section{Discussion}

The mouse writhing assay is a simple and reliable method for rapid evaluation of peripheral type of analgesic action. In this method the abdominal constriction response is induced by acetic acid. Acetic acid causes algesia by liberating endogenous substances including serotonin, histamine, prostaglandins, bradykinin and substance $\mathrm{P}$, which stimulate pain nerve endings ${ }^{[8]}$. The results obtained from this study indicate that EVLSS increased the writhing inhibiting capacity than leaves alone as reported by Haque et al. ${ }^{[4]}$. With EVLSS, the maximum analgesic activity (60.01\%) of $E$. variegata in acetic acid-induced writhing mice was observed at $400 \mathrm{mg} / \mathrm{kg}$ dose, while only leaves at $500 \mathrm{mg} / \mathrm{kg}$ dose has been reported by Haque et al. ${ }^{[4]}$ to demonstrate about $50 \%$ inhibition. These results suggest that some analgesic principles are present in leaves as well as in soft stem and together they possibly exhibit a synergistic analgesic activity. Whether such synergistic activity of leaves and stems is actually the case is currently under investigation. A further exploration of the bioactive molecules exactly responsible for this activity is also currently under investigation.

The obtained results provide a pharmacological evidence for use of both leaves and soft stems of this plant as an analgesic agent.

\section{Acknowledgments}

The authors are thankful to the University of Development Alternative for funding this study and to Bangladesh National Herbarium for plant identification.

\section{References}

1. Germplasm Resources Information Network: Erythrina variegata

2. Whistler, W. A., and Craig, R. E. (2006). Species Profiles for Pacific Island Agroforestry (www.traditionaltree.org). ver. 3.1

3. Ghani, A. (2003). Medicinal Plants of Bangladesh with chemical constituents and uses. 2nd edition; published by Asiatic Society of Bangladesh: pp 222-223.

4. Haque, R., Ali, M. S., Saha, A., and Alimuzzaman, M. (2006). Analgesic Activity of Methanolic Extract of the Leaf of Erythrina variegata. Dhaka Univ. J. Pharm. Sci., 5(1-2): 7779.

5. Kokate C.K.,(1994). Practical Pharmacognosy, Vallabh Prakashan, New Delhi, pp. 105-107.

6. Harborne J.B., 1998. Phytochemical Methods, Chapman \& Hall, London, pp. 60.

7. Mani, V., Gunnam, K. K., and Parle, M. (2007). Antinociceptive and anti-inflammatory effects of Thespesia populnea bark extract. J Ethnopharmacol., 109: 264-270.

8. Ochi, T., Motoyama, Y., Goto, T. (2000). The analgesic effect profile of FR122047, a selective cyclooxygenase-1 inhibitor, in chemical nociceptive models. Eur J Pharmacol., 391:49-54. 